\title{
MILK PRODUCTION COSTS IN POLISH AND OTHER EU COUNTRIES' DAIRY FARMS - ASSESSMENT IN 2009-2015
}

\author{
Andrzej Parzonko ${ }^{1}$, Phd \\ ${ }^{1}$ Faculty of Economics, Warsaw University of Life Sciences, Poland
}

\begin{abstract}
The main purpose of the study was to assess the cost competitiveness of milk production in dairy farms from selected EU countries in the years 2009-2015. In addition, differences in the volume of milk production in individual EU countries were presented and the problem of the scale of milk production in agricultural farms was outlined. According to the study, average dairy farms from selected 10 EU countries significantly differed in the production potential and scale of milk production. The average arable land area of a dairy farm in Poland was only approximately 20 ha of arable land area, while at the same time in the Czech Republic it was at the level of approximately 300 ha of arable land area. The lowest production costs of $100 \mathrm{~kg}$ of produced milk were recorded in Poland, Lithuania and Latvia, while the highest were in Denmark and the Czech Republic. It can be observed that in the years 2009-2015 in nine out of ten analysed countries, the total costs of production of $100 \mathrm{~kg}$ of milk increased (by 2.4 euro on average).
\end{abstract}

Keywords: dairy farms, production scale, cost competitiveness.

JEL code: 0140

\section{Introduction}

Competition is ubiquitous in economic and social life. It also affects agricultural farms, both when two entities face one another and fight for the best possible position or when individual entities (agricultural farms) are not a party in the real market, but their production costs have a major impact on the ability to compete of final products. In the second situation mentioned, the ability to compete of national agriculture as a whole or of a relevant segment of this sector in meant (Wos A., 2001). Then, the agriculture is an element which has a significant impact on the competitiveness of finished products manufactured by food processing units. A considerable part of the costs incurred by the food processing industry are the costs of the raw material. Analysing the costs of production of agricultural raw materials (consumption and prices of production factors) intended for further processing, a potential competitiveness of this element in the distribution channel in relation to the situation in other countries is assessed (Parzonko A., Hornowski A., 2017). Reasons for differentiation of production costs can be compared and the directions of their changes can be considered. The expenditure of the performed production can be affected by factors present inside the farm, or endogenous factors (resources of production factors, organization, people's skills etc.) and external or exogenous factors. The Common Agricultural Policy implemented in the EU is among external factors, which significantly affect the competitiveness of agricultural farms in the EU (Czyzewski A., Guth M., 2016). It involves major changes, including those concerning the milk market. In 2015, the resignation of the EU from the "milk quotas" mechanism became a reality. It worked from 1984 and contributed to the stabilization of the milk market in the EU countries. Each EU Member State had its national milk quota and the production of milk above its level resulted in a fine being paid. It discouraged farmers from producing over the established limit (Malak-Rawlikowska A., 2005). The EU agricultural policy began to change from 2003 towards a greater transformation into market oriented economy of agricultural production (Parzonko A., 2013). Among other things, decisions were made to slowly withdraw the milk production quoting mechanism in the EU. In addition, in 2008 the European Commission proposed to limit the scope of intervention in the milk market. It mainly consisted in: 1) abandoning obligatory subsidies for private storage of butter and fixed intervention prices for butter and skimmed milk powder purchase;, 2) elimination of subsidies for 
private storage of cheeses, subsidies for butter processing, its sale to non-profit organizations and the army etc.; 3) elimination of subsidies for exporting dairy products outside the EU (Guba, Dbrowski 2012). The adopted course of actions of the European Union after 2003 contributes to a deeper liberalization of the milk market and dependence on the global situation. This leads to greater instability in the European milk market. The prices of milk and dairy products depend to a greater extent on the situation on world markets (Parzonko A., 2014). According to the presented proposals of changes in the EU agricultural policy in the milk market, strong, economic farms, where milk production costs are relatively low, are preferred. In relation to the emerging situation, the following question arises: Which is the cost competitiveness of dairy farms from individual EU countries?

The main purpose of the study was to assess the cost competitiveness of milk production in dairy farms from selected EU countries in the years 2009-2015. In addition, differences in the volume of milk production in individual EU countries were presented and the problem of the scale of milk production in agricultural farms was outlined. In order to achieve the planned objective, statistical data from the milk production quoting system applied until 2015 were reviewed, a literature review on this subject was performed, and based on the accounting data of the FADN system, an analysis of milk production costs in farms from selected EU countries was carried out. When determining the cost competitiveness of dairy farms, at first a group of countries to analyse their dairy farms was selected. These were countries important for milk production divided into "old" and "new" EU countries. The material for analysis was data from the FADN system from the years 2009-2015 including the group of farms specialized in milk production. In the paper, costs of milk production in an average dairy farm from a selected country were presented.

\section{Research results and discussion Changes in milk production and the number of dairy farms in the EU countries in the years 2004-2015}

Various historical and macroeconomic conditions, the culture of a specific country, traditions in the consumption and production of milk determine organization of entities involved in the production and processing of milk. The countries of the European Union significantly contribute to the global milk production. In 2015, in 28 EU countries, it accounted for approximately $20 \%$ of the global production and remained on a fairly stable level, with a slight upward trend. However, there were big differences in the level of development of the dairy sector in individual EU countries (Zietara W. et al., 2013). This differentiation resulted primarily from the level of economic development of EU countries depending, among others, on historical events (Parzonko A., 2014). According to the data presented in Table 1, farms involved in milk production in the EU countries are much diversified in terms of the size of their operations. On average, most milk in the quota year 2014/2015 was sold in Slovakia (1659.2 tons), the Czech Republic (1487.7 tons), Denmark (1432.9 tons), Estonia (1087.7 tons), and the United Kingdom (1093.2 tons). At the other extreme, there were farms from Romania (13.6 tons), Lithuania (43.6 tons), Slovenia (47.3 tons), Latvia (80 tons), Poland (80.6 tons).

Very clear differences between individual EU countries are also visible in the total milk production and the number of farms (farming families) involved in the dairy cattle husbandry. According to the data presented in Table 1, the largest milk producers in the EU include such countries as Germany (31.34 million tons), France (24.84 million tons), the United Kingdom (14.79 million tons), the Netherlands (12.46 million tons), Italy (11.0 million tons), Poland 
(10.51 million tons). In the quota year 2014/15, the milk production in the EU was located in 579.981 farms selling milk to dairies. The largest percentage of farms was present in Poland $22.5 \%$, Germany $12.5 \%$, Romania $12.1 \%$, and France $11.5 \%$.

Changes in production and number of farms selling milk to diaries in Table 1. individual EU countries in the quota years $2004 / 2005$ to $2014 / 2015$

\begin{tabular}{|c|c|c|c|c|c|c|c|}
\hline \multirow[t]{2}{*}{ Details } & \multicolumn{3}{|c|}{ Quota year $2014 / 2015$} & \multicolumn{2}{|c|}{$\begin{array}{l}\text { Increase in the } \\
\text { production of milk } \\
\text { delivered to dairies in } \\
\text { the quota years } \\
2004 / 2005- \\
2014 / 2015\end{array}$} & \multicolumn{2}{|c|}{$\begin{array}{c}\text { Decrease in the } \\
\text { number of farms } \\
\text { selling milk to } \\
\text { diaries in the } \\
\text { quota years } \\
2004 / 2005- \\
2014 / 2015\end{array}$} \\
\hline & $\begin{array}{l}\text { Delivery of } \\
\text { milk to diaries } \\
\text { (million tons) }\end{array}$ & $\begin{array}{l}\text { Number of } \\
\text { wholesale } \\
\text { suppliers }\end{array}$ & $\begin{array}{c}\text { Average } \\
\text { supplies } \\
\text { from the } \\
\text { farm in a } \\
\text { year }(t)\end{array}$ & million tons & $\%$ & number & $\%$ \\
\hline Germany & 31.34 & 72.647 & 431.3 & 3.16 & 11.21 & 39.623 & 35.29 \\
\hline France & 24.84 & 66.662 & 372.7 & 1.201 & 5.08 & 41.522 & 38.38 \\
\hline $\begin{array}{l}\text { the United } \\
\text { Kingdom }\end{array}$ & 14.79 & 13.531 & 1.093 .2 & 0.525 & 3.68 & 7.293 & 35.02 \\
\hline $\begin{array}{l}\text { the } \\
\text { Netherlands }\end{array}$ & 12.46 & 17.641 & 706.3 & 1.389 & 12.54 & 5.517 & 23.82 \\
\hline Italy & 11.00 & 30.528 & 360.4 & 0.336 & 3.15 & 18.928 & 38.27 \\
\hline Poland & 10.51 & 130.263 & 80.6 & 2.159 & 25.87 & 180.197 & 58.04 \\
\hline Spain & 6.55 & 17.678 & 370.5 & 0.43 & 7.02 & 17.861 & 50.26 \\
\hline Ireland & 6.04 & 18.430 & 327.7 & 0.602 & 11.07 & 5.766 & 23.83 \\
\hline Denmark & 4.93 & 3.444 & 1.432 .9 & 0.478 & 10.73 & 3.091 & 47.3 \\
\hline Belgium & 3.65 & 8.411 & 433.6 & 0.352 & 10.7 & 6.007 & 41.66 \\
\hline Austria & 3.07 & 33.322 & 92.2 & 0.393 & 14.69 & 17.716 & 34.71 \\
\hline Sweden & 2.87 & 4.931 & 581.7 & -0.336 & -10.49 & 4.485 & 47.63 \\
\hline $\begin{array}{l}\text { the Czech } \\
\text { Republic }\end{array}$ & 2.69 & 1.811 & 1.487 .7 & 0.304 & 12.72 & 1.139 & 38.61 \\
\hline Finland & 2.34 & 8.985 & 260.8 & -0.008 & -0.35 & 8.773 & 49.40 \\
\hline Portugal & 1.87 & 6.093 & 306.7 & -0.05 & -2.59 & 9.627 & 61.24 \\
\hline Hungary & 1.59 & 2.641 & 601.1 & 0.131 & 8.98 & 2.553 & 49.15 \\
\hline Lithuania & 1.46 & 33.472 & 43.6 & 0.35 & 31.62 & 74.691 & 69.05 \\
\hline Slovakia & 0.86 & 519 & 1.659 .2 & -0.015 & -1.75 & 281 & 35.13 \\
\hline Latvia & 0.76 & 9.551 & 80 & 0.304 & 66.23 & 14.858 & 60.87 \\
\hline Estonia & 0.70 & 640 & 1.087 .7 & 0.181 & 35.03 & 945 & 59.62 \\
\hline Greece & 0.62 & 3.351 & 185.2 & -0.102 & -14.09 & 4.384 & 56.68 \\
\hline Bulgaria & 0.46 & 6.855 & 66.5 & 0.031 & 23.85 & 32 & 13.56 \\
\hline Luxemburg & 0.31 & 716 & 434.8 & 0.04 & 14.9 & 275 & 27.75 \\
\hline Malta & 0.04 & 117 & 364.8 & 0.001 & 1.92 & 33 & 22 \\
\hline
\end{tabular}

Source: author's elaboration based on the press release of the European Commission "Twe/ve Member States exceeded their 2014/15 milk quota", Brussels 21.10.2015,

http://ec.europa.eu/agriculture/newsroom/232_en.htm, retrieved: 9.01.2018

Considering the directions of changes in milk production in individual EU countries over subsequent years, it is worth investigating the changes which took place in the previous decade. Despite the compulsory system limiting the increase in milk production in all EU countries - the "milk quota mechanism" - changes occurred. They took place with varying intensity in different EU countries (Table 1). The largest increase in milk produced, which reached dairies, occurred in Germany ( 3.16 million tons), Poland ( 2.16 million tons), the Netherlands (1.39 million tons), 
France ( 1.20 million tons), Ireland ( 0.60 million tons). In five EU countries, milk production in the quota year 2014/2015 was lower than in 2004/2005. In general, in the analysed period milk production in the EU increased by 11.86 million tons, which accounted for $8.9 \%$ of production from the quota year 2004/2005. A very important issue, worthy of clear emphasizing, is the process of decrease in the number of farms involved in dairy cattle husbandry and production of milk for sale. In the analysed decade (quota years 2004/2005 - 2014/2015), the number of so-called wholesale suppliers decreased in the analysed 24 EU countries by 456.597, which constituted almost a half of all suppliers from the year 2004/2005. In particular, the process of decreasing the number of farms involved in dairy cattle husbandry and milk production took place in countries characterized by a significant number of farms with a relatively small scale of production. The highest percentage reduction of farms took place in Lithuania (69\%), Latvia (61\%), Portugal (61\%), Poland (58 \%), and Spain $(50 \%)$. The decrease in the number of farms involved in cattle husbandry and milk production was apparently accompanied by the process of increase in the scale of production in the entities, in which a decision to continue this activity was made. The largest increases in annual production of milk sold to dairies from an average farm took place in such countries as Estonia (762 tons), Denmark (750.9 tons), the Czech Republic (677.4 tons), Slovakia (563.6 tons), the United Kingdom (408.1 tons).

\section{Costs of milk production in dairy farms from selected EU countries}

The measure of the cost competitiveness of milk production in agricultural farms in Poland and other countries is the expenditure for production, or the cost of production of a production unit (in the case of the analysed issue - the cost of production of $100 \mathrm{~kg}$ of milk). When determining the expenditure for milk production, various methodological doubts appear. The most important of them include: 1) the way of recognizing different costs (mainly indirect) and assigning them to the activity, which is milk production; 2) milk produced in different farms may differ in the content of individual components (e.g. protein, fat etc.). Among agricultural economists, there are different approaches in the methodology of determining production costs. So-called analytical and synthetic approaches were developed. Supporters of the first approach treat an agricultural farm as a set of mutually independent production activities, for which revenues and costs, and resulting profit (income) can be calculated. Economists opting for the synthetic approach treat an agricultural farm as an organic unit, where it is not possible to correctly divide all and especially indirect costs between individual activities because of numerous and close relationships between production sectors, branches and activities (Zietara, 2009). Despite actual methodical difficulties with accurate attribution of appropriate costs (especially indirect ones) to the manufactured product (which is milk in the analysed case), there are information needs, in particular of financial analysts and policy makers, of delivery of synthetic and precise information about the cost of unit production of a given product. Therefore, many organizations, including the European Dairy Farmers Association (EDF) and the International Farm Comparison Network (IFCN) provide information on the production cost of $100 \mathrm{~kg}$ of milk, trying to logically divide and assign direct and indirect costs incurred in an agricultural farm (Hemme T., 2013). In this paper, the author, based on data from the European FADN, considered the average direct costs of cattle husbandry in the group of farms specialized in milk production, while indirect costs (divided into the costs of general economy and external factors) were divided and assigned to the activity, which is milk production, in a part 
corresponding to the percentage share of revenues from cattle husbandry and milk production, within the total revenue of an agricultural farm.

According to the data presented in Table 2, average dairy farms from selected $10 \mathrm{EU}$ countries significantly differed in the production potential and scale of milk production. The average arable land area of a dairy farm in Poland was only approximately 20 ha of arable land area, while at the same time in the Czech Republic it was at the level of approximately 300 ha of arable land area. The average number of dairy cows in a Polish farm was also very small and in the years 2009-2015 varied in the range of 13.9 and 16.7 animals. A similar level of the average number of kept cows was in Lithuania and Latvia. In other compared EU countries, the average number of cows and milk production were at a significantly higher level. When analysing the costs of milk production, relatively large differences between the analysed average dairy farms from selected 10 countries can be observed (Table 2). The lowest production costs of $100 \mathrm{~kg}$ of milk were recorded in Poland, Lithuania and Latvia, while the highest were in Denmark and the Czech Republic. In general, it should be stated that in smaller dairy farms, in which the cattle husbandry was performed by a farmer and his family, the actual production costs of $100 \mathrm{~kg}$ of milk were lower. It resulted, among other, from the fact, that the presented calculation did not include the costs of own work of the farmer and his family. In dairy farms in Western Europe, the highest costs of milk production were recorded in Denmark. It resulted from relatively high direct costs and high costs of external factors, especially bank interest rates. An important element in the assessment of production costs is their structure. In the years 2009-2015, the average share of costs of external factors (lease fee, remuneration, and interest rates) in the structure of total costs of produced milk ranged from $7 \%$ in Polish farms to $30 \%$ in Danish farms. A big difference in this area resulted in particular from high costs of interest on capital and remuneration in Danish farms. When assessing changes in milk production costs in the years 2009-2015, it can be observed that in nine out of ten analysed countries, the total costs of production of $100 \mathrm{~kg}$ of milk increased (by 2.4 euro on average). Only in Denmark the average unit cost in 2015 was lower by 1.6 euro/100 kg of produced milk in comparison with 2009.

When assessing the competitiveness of dairy farms from the analysed countries, it is worth paying attention to the total income generated on a farm, which includes a payment for the farmer's work and the assets involved. In 2015, on average, the highest income from a dairy farm was generated in the Netherlands (60.506 euro), while Czech (56.286 euro) and Hungarian farms (2.747 euro) incurred losses. 
Average production potential and costs of milk production in dairy farms from

Table 2. selected EU countries in the years 2009-2015

\begin{tabular}{|c|c|c|c|c|c|c|c|c|c|c|}
\hline \multirow{2}{*}{ Details } & \multicolumn{10}{|c|}{ Selected EU countries } \\
\hline & DE & $\mathbf{F R}$ & GB & NL & DK & PL & $\mathbf{C Z}$ & HU & LT & $\mathbf{L V}$ \\
\hline \multicolumn{11}{|c|}{ Year 2009} \\
\hline Total Utilised Agricultural Area (ha) & 70.6 & 83.5 & 106.6 & 49.4 & 143.5 & 19.7 & 282.7 & 93.5 & 34.0 & 51.8 \\
\hline Number of cows & 53.3 & 50.3 & 118.7 & 80.7 & 144.1 & 13.9 & 101.3 & 41.2 & 11.7 & 14.6 \\
\hline Milk yield (kg/year) & 7268 & 6371 & 7036 & 7837 & 8385 & 4997 & 6188 & 6479 & 5106 & 5275 \\
\hline $\begin{array}{l}\text { Total specific costs (euro/100 kg of } \\
\text { milk) }\end{array}$ & 11.5 & 10.3 & 16.6 & 10.8 & 21.8 & 9.4 & 18.8 & 19.8 & 13.4 & 15.9 \\
\hline $\begin{array}{l}\text { Total farming overheads (euro/ } 100 \mathrm{~kg} \\
\text { of milk) }\end{array}$ & 10.7 & 13.0 & 6.0 & 8.9 & 7.5 & 5.3 & 10.3 & 7.6 & 4.8 & 6.7 \\
\hline $\begin{array}{l}\text { Of which: Machinery \& building current } \\
\text { costs }\end{array}$ & 2.8 & 2.7 & 1.7 & 2.5 & 2.4 & 1.7 & 2.4 & 1.2 & 1.3 & 1.7 \\
\hline Energy & 3.0 & 1.8 & 1.4 & 1.5 & 1.1 & 2.2 & 3.9 & 3.2 & 2.1 & 3.3 \\
\hline Depreciation & 5.7 & 8.7 & 3.0 & 5.4 & 4.3 & 4.9 & 3.9 & 2.2 & 4.3 & 4.3 \\
\hline $\begin{array}{l}\text { Costs of external factors (euro/kg of } \\
\text { milk) }\end{array}$ & 5.5 & 4.9 & 3.6 & 6.9 & 12.6 & 1.0 & 10.0 & 6.9 & 2.1 & 3.0 \\
\hline Of which: Wages paid & 2.3 & 0.8 & 2.2 & 0.7 & 3.1 & 0.3 & 8.7 & 5.1 & 0.9 & 2.1 \\
\hline Rent paid & 2.0 & 2.6 & 0.8 & 1.6 & 1.4 & 0.3 & 0.7 & 1.0 & 0.4 & 0.2 \\
\hline Interest paid & 1.2 & 1.5 & 0.6 & 4.6 & 8.1 & 0.4 & 0.6 & 0.8 & 0.7 & 0.7 \\
\hline Total costs (euro/100 kg of milk) & 25.6 & 26.6 & 23.6 & 25.4 & 36.0 & 14.1 & 31.9 & 27.4 & 15.1 & 19.9 \\
\hline \multicolumn{11}{|c|}{ Year 2011} \\
\hline Total Utilised Agricultural Area (ha) & 69.6 & 87.1 & 106.1 & 49.8 & 141.0 & 21.3 & 281.2 & 93.4 & 31.1 & 49.7 \\
\hline Number of cows & 54.1 & 52.5 & 120.8 & 81.7 & 143.9 & 15.0 & 98.2 & 41.2 & 10.7 & 14.4 \\
\hline Milk yield (kg/year) & 7532 & 6936 & 7429 & 7984 & 8417 & 5069 & 6448 & 6627 & 5322 & 5423 \\
\hline $\begin{array}{l}\text { Total specific costs (euro/100 kg of } \\
\text { milk) }\end{array}$ & 14.4 & 11.0 & 18.3 & 13.2 & 25.0 & 11.0 & 20.9 & 23.5 & 15.2 & 18.3 \\
\hline $\begin{array}{l}\text { Total farming overheads (euro/ } 100 \mathrm{~kg} \\
\text { of milk) }\end{array}$ & 12.1 & 13.3 & 5.9 & 9.8 & 8.1 & 6.3 & 13.7 & 9.4 & 6.5 & 9.3 \\
\hline $\begin{array}{l}\text { Of which: Machinery \& building current } \\
\text { costs }\end{array}$ & 3.3 & 2.7 & 1.1 & 2.7 & 2.6 & 1.8 & 3.5 & 1.8 & 1.7 & 2.8 \\
\hline Energy & 3.5 & 2.2 & 1.7 & 1.8 & 1.4 & 2.8 & 4.9 & 4.4 & 3.0 & 4.3 \\
\hline Depreciation & 6.1 & 7.8 & 3.3 & 5.9 & 4.2 & 5.0 & 4.5 & 2.8 & 6.0 & 4.2 \\
\hline $\begin{array}{l}\text { Costs of external factors (euro/kg of } \\
\text { milk) }\end{array}$ & 5.4 & 4.4 & 3.8 & 7.2 & 10.8 & 1.1 & 11.8 & 8.4 & 1.7 & 3.3 \\
\hline Of which: Wages paid & 2.4 & 0.7 & 2.3 & 0.7 & 3.0 & 0.4 & 10.1 & 5.7 & 1.0 & 2.6 \\
\hline Rent paid & 1.9 & 2.4 & 0.8 & 1.9 & 1.5 & 0.4 & 1.0 & 1.7 & 0.4 & 0.2 \\
\hline Interest paid & 1.1 & 1.4 & 0.6 & 4.6 & 6.3 & 0.4 & 0.8 & 1.0 & 0.4 & 0.5 \\
\hline Total costs (euro/100 kg of milk) & 29.0 & 27.0 & 25.6 & 29.0 & 36.7 & 15.7 & 38.3 & 32.9 & 18.7 & 25.5 \\
\hline \multicolumn{11}{|c|}{ Year 2015} \\
\hline Total Utilised Agricultural Area (ha) & 72.1 & 91.1 & 111.8 & 51.0 & 156.8 & 21.9 & 327.1 & 81.8 & 27.8 & 50.9 \\
\hline Number of cows & 62.5 & 58.8 & 136.4 & 91.2 & 165.2 & 16.7 & 116.7 & 43.7 & 9.8 & 16.3 \\
\hline Milk yield (kg/year) & 7589 & 6947 & 7311 & 8169 & 9585 & 5417 & 7157 & 6819 & 5342 & 5913 \\
\hline $\begin{array}{l}\text { Total specific costs (euro/100 kg of } \\
\text { milk) }\end{array}$ & 13.9 & 11.4 & 20.5 & 16.9 & 23.6 & 10.5 & 19.8 & 21.5 & 15.6 & 16.9 \\
\hline $\begin{array}{l}\text { Total farming overheads (euro/ } 100 \mathrm{~kg} \\
\text { of milk) }\end{array}$ & 10.2 & 14.0 & 7.1 & 8.8 & 7.6 & 6.4 & 10.8 & 7.6 & 6.1 & 7.1 \\
\hline $\begin{array}{l}\text { Of which: Machinery \& building current } \\
\text { costs }\end{array}$ & 3.4 & 3.8 & 2.2 & 2.4 & 2.7 & 2.1 & 4.3 & 1.8 & 1.9 & 2.3 \\
\hline Energy & 2.8 & 2.2 & 1.5 & 1.7 & 1.1 & 2.7 & 3.7 & 3.2 & 2.4 & 3.3 \\
\hline Depreciation & 5.2 & 7.8 & 3.6 & 5.1 & 3.8 & 6.2 & 5.0 & 2.7 & 6.6 & 3.7 \\
\hline $\begin{array}{l}\text { Costs of external factors (euro/kg of } \\
\text { milk) }\end{array}$ & 5.4 & 4.5 & 4.7 & 5.6 & 8.9 & 1.2 & 11.3 & 7.9 & 1.9 & 3.6 \\
\hline Of which: Wages paid & 2.3 & 0.9 & 2.8 & 0.9 & 3.4 & 0.3 & 9.3 & 6.2 & 1.0 & 3.0 \\
\hline Rent paid & 2.1 & 2.5 & 1.1 & 1.3 & 1.4 & 0.5 & 1.3 & 1.4 & 0.6 & 0.3 \\
\hline Interest paid & 1.0 & 1.2 & 0.7 & 3.3 & 4.1 & 0.4 & 0.7 & 0.3 & 0.2 & 0.3 \\
\hline Total costs (euro/100 kg of milk) & 26.7 & 28.3 & 29.1 & 29.1 & 34.4 & 16.9 & 33.2 & 28.9 & 17.9 & 21.2 \\
\hline
\end{tabular}


Source: author's elaboration based on: http:// http://ec.europa.eu/agriculture/rica/database/database_de.cfm

\section{Summary and conclusions}

The direction of the agricultural policy of the European Union adopted after 2008 contributes to a deeper liberalization of the milk market and dependence on the global situation. The prices of milk and dairy products in the EU depend to a greater extent on the situation on the world markets. According to the adopted direction of changes in agricultural policy in the milk market, strong, economic farms, where milk production costs are relatively low, are preferred.

Based on the conducted research it can be concluded that:

1) there were big differences in the level of development of the dairy sector in individual EU countries and the largest milk producers in the EU include such countries as Germany (31.34 million tons), France (24.84 million tons), the United Kingdom (14.79 million tons), the Netherlands (12.46 million tons), Italy (11.0 million tons), Poland (10.51 million tons);

2) farms involved in milk production in the EU countries are much diversified in terms of the size of their operations. On average, most milk in the quota year 2014/2015 was sold in Slovakia (1659.2 tons), the Czech Republic (1487.7 tons), Denmark (1432.9 tons), Estonia (1087.7 tons), and the United Kingdom (1093.2 tons). At the other extreme there were farms from Romania (13.6 tons), Lithuania (43.6 tons), Slovenia (47.3 tons), Latvia ( 80 tons), Poland (80.6 tons);

3) There were relatively large differences in the costs of milk production between average milk farms in individual EU countries. The lowest production costs of $100 \mathrm{~kg}$ of milk were recorded in Poland, Lithuania and Latvia, while the highest were in Denmark and the Czech Republic.

\section{Bibliography}

1. Czyzewski, A., Guth, M. (2016). Zroznicowanie produkcji mleka w makroregionach Unii Europejskiej z wyroznieniem Polski (Diversification of milk production in macro-regions of the European Union with the distinction of Poland), Warszawa: Wydawnictwo PWN.

2. Guba, W., Dabrowski, J. (2012). Deregulacje rynku mleka w UE - Skutki i zalecenia dla Polski (Deregulation of the EU milk market - Effects and recommendations for Poland), Roczniki Nauk Ekonomicznych, Seria G Ekonomka rolnictwa, Tom 99, Zeszyt 1.

3. http://ec.europa.eu/agriculture/newsroom/232_en.htm, "Twelve Member States exceeded their 2014/15 milk quota" (press release of the European Commission), Brussels 21.10.2015, retrieved: 9.01.2018the

4. Malak - Rawlikowska A. (2005). Ekonomiczne i organizacyjne skutki wprowadzenia systemu regulacji produkcji mleka w wybranych krajach Unii Europejskiej i w Polsce na przykladzie systemu kwotowania produkcji mleka (Economic and organizational effects of the introduction of the milk production regulation system in selected European Union countries and in Poland on the example of the milk production quoting system), Warszawa: Wydawnictwo SGGW

5. Parzonko, A. (2013). Globalne i lokalne uwarunkowania rozwoju produkcji mleka (Global and local conditions for the development of milk production), Warszawa: Wydawnictwo SGGW.

6. Parzonko, A. (2014). Economic and Social Issues Related with the Development of Dairy Farms in Poland; Economic Science for Rural Development; nr 35, pp. 199-207.

7. Parzonko, A. (2014). Procesy globalizacji i regionalizacji produkcji mleczarskiej - szanse i zagrozenia dla polskich rolników (Processes of globalization and regionalization of dairy production - opportunities and threats for Polish farmers ), (In:) Hodowla i chow bydla w badaniach naukowych i w praktyce (Cattle breeding in scientific research and in practice): XXII Szkoła Zimowa Hodowców Bydła (13 ark); Uniwersytet Rolniczy im. Hugona Kołłątaja w Krakowie

8. Parzonko, A., Hornowski, A. (2017).Economic and Social Assessment of the Use of Structural Funds in the Creation of the Development of "Small" Farms in Poland; Journal of Agribusiness and Rural Development 2017, nr 2, pp. 413-420

9. Parzonko, A., Runowski, H. (2015). Rozwoj produkcji zwierzęcej w swietle aktualnych uwarunkowan (The development of animal production under current conditions); Przegląd Hodowlany 2015, R. 83, nr 5, pp. 913.

10. Hemme, T. (2013). Dairy Report, International Farm Comparison Network.

11. Wos, A. (2001). Konkurencyjnosc potencjalna polskiego rolnictwa (The potential competitiveness of Polish agriculture), Warszawa: Wydawnictwo IERiGż, , pp. 7 
12. Ziętara, W. (2009). Rachunek kosztow w przedsiebiorstwach rolniczych w teorii i praktyce (Cost accounting in agricultural enterprises in theory and practice), Journal of Agribusiness and Rural Development, nr 2(12), Poznan.

13. Ziętara, W. (2015). Gospodarstwa i przedsiebiorstwa rolnicze jako podstawowe ogniwo lancucha zywnosciowego (Farms and agricultural enterprises as the basic link in the food chain), Roczniki Naukowe Stowarzyszenia Ekonomistow Rolnictwa i Agrobiznesu, 2015, tom 17, zeszyt 4, pp. 376-382.

14. Ziętara, W., Adamski, M., Grodzki, H. (2013). Polskie gospodarstwa z chowem bydla na tle wybranych krajow (Polish farms with cattle production in comparison with selected countries), Warszawa: Wydawnictwo Instytut Ekonomiki Rolnictwa i Gospodarki Zywnosciowej. 